JIIP: Jurnal IImiah IImu Pemerintahan

Volume 5, Nomor 2, Tahun 2020

DOI: 10.14710/jiip.v5i2.7737

\title{
Konflik Pemilu: Dinamika Sengketa Calon Perseorangan dalam Kontestasi Elektoral di Kabupaten Lebak
}

\author{
Mahpudin \\ Departemen Politik Pemerintahan, Universitas Gadjah Mada
}

Dikirimkan: 5 April 2020

Direvisi: 2 Juni 2020

Diterbitkan: 30 September 2020

\section{INTISARI}

Artikel ini membahas sengketa konflik antara calon perseorangan dan penyelengaraa pemilu dalam kontestasi elektoral pada Pilkada Kabupaten Lebak tahun 2018. Mengapa terjadi sengketa pemilu antara calon perseorangan dengan lembaga penyelenggara pemilu dan Bagaimana resolusi konflik sengketa calon perseorangan dalam kontestasi elektoral pada Pilkada Kabupaten Lebak merupakan dua pertanyaan yang hendak dijawab dalam tulisan ini. Metode penelitian yang dipilih adalah kualitatif dengan pendekatan studi kasus. Pengumpulan data dilakukan berdasarkan studi kepustakaan dan berita online. Hasil penelitian mengungkap bahwa sengketa terjadi karena adanya ketidakpuasan bakal calon perseorangan yaitu Cecep Sumarno-Didin Saprudin terkait keputusan KPU Kabupaten Lebak yang menolak berkas pendaftaran sebagai calon kandidat. Penolakan tersebut dikarenakan tidak memenuhi syarat dukungan minimal. Resolusi konflik yang digunakan untuk mengatasi sengketa tersebut adalah dengan metode adjudikasi. Hal ini dipilih sebab pihak yang berkonflik tidak pernah menemui kesepakatan bersama ketika dihadapkan melalui proses musyawarah yang diselenggarakan oleh Bawaslu Kabupaten Lebak. Mekanisme adjudikasi dapat dijalankan oleh Bawaslu Kabupaten Lebak karena undang-undang memberi kewenangan kepada Bawaslu untuk menjalankan fungsi pengadilan khususnya mengenai penyelesaian sengketa proses pemilu.

calon perseorangan; konflik; KPU lebak; sengketa

\section{Pendahuluan}

onflik dalam pemilu merupakan sebuah keniscayaan. Hal ini dikarenakan
pemilu adalah arena kontestasi para aktor untuk memperebutkan
kekuasaan. Karena itu, konflik pemilu tidak mungkin dapat dihilangkan. Sebab, pemilu itu sendiri adalah mekanisme menajemen konflik yang mengatur dan mengelola bagaimana kekuasaan dikontestasikan agar lebih terlembaga, legal, dan mendapat legitimasi publik. Tulisan ini membahas tentang konflik pemilu khususnya dinamika sengketa bakal calon perseorangan dalam kontestasi elektoral di tingkat lokal dengan mengambil lokus penelitian pada Pemilihan Kepala Daerah (Pilkada) di Kabupaten Lebak tahun 2018.

Korespodensi:

Program Master Ilmu Politik dan Pemerintahan, Universitas Gadjah Mada, Jl. Sosio Yustisia No.1, Karang Malang, Caturtunggal, Kec. Depok, Kabupaten Sleman, Daerah Istimewa Yogyakarta 55281

Email: mahpudin95@mail.ugm.ac.id 
Kajian ini menjadi penting untuk dibahas dengan beberapa pertimbangan: pertama, isu mengenai calon perseorangan belakangan menjadi diskursus baru dalam politik elektoral menyusul dikeluarkannya regulasi yang memberi kesempatan kepada masyarakat untuk ikut berpartisipasi dalam kontestasi elektoral tanpa harus melalui jalur partai politik. Kebijakan ini tidak lepas sebagai upaya melawan dominasi dan hegemoni partai politik yang cenderung elitis dan oligarkis dalam proses rekrutmen politik sehingga menutup ruang politik bagi masyarakat (Robison \& Hadiz, 2004; Winters, 2014). Selain itu kebijakan ini berangkat dari fakta empiris yang menunjukkan lemahnya kepercayaan publik (public distrust) terhadap institusi partai politik (Efriza, 2019).

Kedua, kendati regulasi pemilu memberikan kesempatan kepada calon perseorangan, namun dinamika politik yang berkembang dalam kontestasi elektoral, eksistensi calon perseorangan selalu lemah disebabkan oleh banyak faktor terutama sulitnya memenuhi syarat dukungan minimal sebagaimana yang diamanatkan oleh regulasi pemilu. Tidak jarang hal tersebut sering bermuara pada terjadinya konflik politik antara calon perseorangan dengan lembaga pemilu karena didasari oleh ketidakpuasan atau kekecewaan calon perseorangan terhadap keputusan politik yang dikeluarkan oleh lembaga pemilu, khususnya Komisi Pemilihan Umum (KPU) sebagai lembaga pelaksana teknis kepemiluan. Karena itu penting untuk melihat secara lebih mendalam bagaimana dinamika resolusi konflik terkait sengketa calon perseorangan dalam Pilkada.

Awalnya, partai politik menjadi salah satu aktor utama dalam pemilu. Hal ini tidak lepas sebab eksistensi partai politik tidak lain sebagai sebuah organisasi politik yang bertujuan untuk mendapatkan kekuasaan melalui pemilu (Lowery et al., 2013). Kendati demikian, permasalahan mulai muncul ketika partai tidak mampu menjalankan peran dan fungsinya dengan baik dalam menjaga dan mengawal marwah demokrasi. Di Indonesia, keberadaan partai politik sejak era reformasi tahun 1999 sampai sekarang terus mengalami degradasi kepercayaan publik (Efriza, 2019). Hasil survei terbaru yang dilakukan oleh LSI (Lembaga Survei Indonesia) pada tahun 2019 mengungkap bahwa tingkat kepercayaan masyarakat terhadap partai sangat rendah yaitu hanya mencapai 53 persen dalam empat tahun terkakhir (Katadata.co.id, 2019). Partai saat ini mengarah pada praktik yang tidak demokratis. Banyak para ahli menilai bahwa partai-partai yang ada di Indonesia saat ini dikendalikan oleh logika kartel Roth (2009) dan Slater (2004) mencerminkan wajah yang elitis dan oligarkis (Robison \& Hadiz, 2004; Winters, 2014).

Oleh karena itu, sejak diperkenalkannya sistem pemilihan langsung di Indonesia, partai politik tidak lagi menjadi satu-satunya aktor dalam politik elektoral terutama dalam konteks pemilu di tingkat lokal. Pasca dikeluarkannya Putusan Mahkamah Konstitusi Nomor 5/PUU-V/2007 tanggal 23 Juli 2007 tentang Calon Perseorangan, masyarakat dapat berpartisipasi dalam kontestasi elektoral tanpa melalui dukungan dari partai politik. Keputusan MK ini mendapat legal standing yang sangat kuat dengan dikeluarkannya Undang-undang Nomor 12 tahun 2008 tentang pemerintahan daerah 
yang salah satu pokok pembahasannya mengatur bahwa calon kandidat kepala daerah (gubernur, bupati, walikota) dapat berasal dari partai politik atau jalur perseorangan. Dari sini pula terdapat pergeseran paradigma kekuasaan yang semula kompetisi kekuasaan hanya berkelindan ditangan partai politik namun sekarang kekuasaan dapat terbagi ke kandidat lain di luar partai politik. Hingga saat ini, calon kandidat dari jalur perseorangan masih dipertahankan dalam Pilkada. Sehingga secara tidak langsung, calon perseorangan menjadi bagian penting dalam dinamika politik lokal.

Meskipun calon perseorangan memiliki kesempatan politik untuk berkompetisi dalam arena elektoral, tetapi eksistensinya masih belum signifikan. Pada banyak kasus, calon perseorangan sering kali menemukan kegagalan sebelum berperang karena terhambat oleh regulasi terkait persyaratan pencalonan. Undang-Undang Nomor 10 tahun 2016 mewajibkan calon perseorangan untuk untuk memenuhi syarat dukungan jumlah penduduk yang mempunyai hak pilih dan termuat dalam daftar pemilih tetap. Syarat dukungan tersebut dibuktikan dengan fotokopi kartu tanda kependudukan. Besaran jumlah dukungan berbeda tergantung pada besaran jumlah penduduk di suatu daerah. Persyaratan dukungan ini kerap kali membuat calon perseorangan menemukan kesulitan sehingga tidak sedikit yang berusaha melakukan berbagai cara untuk mendapatkan dukungan pemilih demi memenuhi persyaratan administratif sekalipun dengan tindakan manipulasi data dukungan.

Terkait dengan hal tersebut, calon perseorangan harus berjuang menghadapi dua aktor atau lembaga yang berbeda dalam proses kandidasi elektoral. Pertama, sebelum pemilu dimulai, calon perseorangan harus berhadapan dengan KPU di tingkat daerah terkait dengan persyaratan pencalonan. Tahap ini menjadi penting sebab KPU daerah memiliki kewenangan untuk menerima atau menolak pendaftaran bakal calon kandidat sesuai dengan aturan yang berlaku. Jika pada tahap pendaftaran saja tidak lolos, maka dapat dipastikan langkah calon perseorangan untuk maju dalam kontestasi elektoral akan terhenti. Kedua, calon perseorangan akan berhadapan dengan calon kandidat yang diusung oleh partai. Tentu hal ini memberi hambatan politik yang cukup berarti sebab calon kandidat yang berasal dari partai memiliki modal politik yang lebih besar seperti basis massa dan modal material terkait dengan dana kampanye dibandingkan dengan calon perseorangan yang harus memiliki strategi politik lebih ampuh dalam mengalahkan dominasi calon kandidat dari jalur partai.

Berdasarkan kajian literatur yang ada, konflik pemilu yang melibatkan calon perseorangan belum banyak dibahas. Kajian sebelumnya lebih banyak membahas konflik pemilu yang melibatkan aktor atau institusi partai politik maupun calon kandidat yang diusung oleh partai dalam proses pendaftaran, kampanye, maupun tahapan pemilu lainnya (Armunanto, 2015; Devi, 2019; Ramadlan \& Wahyudi, 2016). Implikasinya, resolusi konflik yang dijalankan oleh Bawaslu mengarah pada aktor yang spesifik yaitu partai atau calon kandidat yang berasal dari partai politik (Aermadepa, 2019; Firdaus, 2014). Sementara, kajian yang secara spesifik membahas isu tentang 
calon perseorangan cenderung hanya memotret dari sudut pandang bekerjanya logika politik elektoral dan implikasinya terhadap konsolidasi demokrasi (Pratikno, 2007; Santoso, 2018; Warjiyati, 2014).

Warjiyati (2014) meletakkan diskursus tentang calon perseorangan sebagai sebuah pilihan yang dilematis sebab dalam kenyataanya menghadapi berbagai problem misalnya, hambatan modal ekonomi dan politik, persyaratan yang sulit dipenuhi dan relasi kekuasaan eksekutif dan legisItaif yang rumit apabila calon perseorangan berhasil memenangkan kontestasi elektoral karena tidak memiliki dukungan politik di parlemen. Hal ini didukung dari hasil kajian Santoso (2018) yang menyebut bahwa kendati keberadaan calon perseorangan sebagai bentuk terbuknya politik yang lebih inklusif, tetapi sepak terjang calon perseorangan masih memiliki banyak hambatan. Pratikno (2007) melihat keberadaan calon perseorangan yang awalnya digadang-gadang dapat memberi efek terhadap proses reformasi elektoral dan institusionalisasi partai politik, tetapi dalam praktiknya hal, hal tersebut sulit dicapai sebab konflik internal yang mengakar kuat dan pragmatisme partai menjadi hambatan yang sangat signifikan terhadap proses reformasi politik.

Melalui telaah literatur, dapat dilihat bahwa kajian yang secara spesifik membahas tentang isu calon perseorangan yang dikaitkan dengan sengketa atau konflik pemilu belum muncul. Karena itu, tulisan ini mencoba mengisi kekosongan kajian dengan spesifik membahas sengketa calon perseorangan pada kontestasi elektoral. Pilkada Lebak tahun 2018 menjadi lokus dalam tulisan ini. Pemilihan lokus kajian ini dikarenakan pada Pilkada Kabupaten Lebak terdapat dua pasangan bakal calon perseorangan yang menggugat KPU Kabupaten Lebak terkait dengan keputusan KPU Kabupaten Lebak yang menyatakan bahwa dua pasangan calon perseorangan tidak memenuhi persyaratan administratif dukungan minimal.

Menariknya, konflik terus memuncak dengan melibatkan pihak lain yaitu Dewan Kehormatan Lembaga Pemilu (DKPP) yang berujung pada diberikannya sanksi administratif dari DKPP kepada KPU Kabupaten Lebak karena melakukan pelanggaran kode etik sebagaimana yang dilaporkan oleh bakal calon perseorangan sebagai Pemohon. Mengapa terjadi sengketa pemilu antara calon perseorangan dengan lembaga penyelenggara pemilu dan Bagaimana resolusi konflik sengketa calon perseorangan dalam kontestasi elektoral pada Pilkada Kabupaten Lebak merupakan dua pertanyaan yang hendak dijawab dalam tulisan ini. Penulis berargumen bahwa sengketa pemilu terjadi karena dilatarbelakangi oleh ketidakpuasan bakal pasangan calon terhadap keputusan KPU Lebak terkait dengan syarat dukungan pencalonan. Sementara resolusi konflik dalam penanganan sengketa di Bawaslu melalui jalur adjudikasi. Kekalahan bakal pasangan calon dalam sengketa di Bawaslu Lebak mempertegas temuan sebelumnya bahwa eksistensi calon perseorangan masih lemah untuk ikut berpartisipasi dalam kontestasi elektoral. 
Artikel ini menggunakan desain penelitian kualitatif-deskriptif dengan pendekatan studi kasus. Secara spesifik kasus yang dimaksud dalam penelitian ini adalah sengketa calon perseorangan pada Pilkada Kabupaten Lebak tahun 2018. Artikel ini menggunkan data sekunder melalui studi literatur dari buku, jurnal, dan artikel yang dianggap relevan untuk menjawab rumusan masalah. Selain itu, peneliti juga melakukan pengumpulan data dan informasi yang diperoleh dari sumber-sumber berita di media online yang secara spesifik membahas tentang sengketa calon perseorangan pada Pilkada Lebak.

\section{Konflik, Resolusi Konflik, dan Sengketa Pemilu}

Konflik merupakan sebuah keniscyaan dalam hubungan sesama manusia (Cressey, 1950). Karena itu konflik tidak dapat dihilangkan justru konflik harus dikelola agar dapat diminimalisir dan tidak memberikan efek destruktif terhadap tatanan sosial dan politik. Pemilu sendiri merupakan manajemen konflik yang mengelola persaingan diantara calon kandidat atau partai politik dalam memperebutkan jabatan dan akses terhadap kekuasaan yang terbatas. Dengan demikian, konflik atau sengketa dalam pemilu sangat mungkin terjadi ketika terdapat benturan kepentingan diantara berbagai aktor. Konflik pemilu dapat terjadi antar peserta pemilu atau antara perserta pemilu dengan lembaga penyelenggara pemilu khususnya KPU terkait dengan keputusan yang dianggap merugikan kepentingan salah satu pihak.

Menurut Wallensteen (2018) konflik didefiniskan sebagai situasi dimana minimal terdapa dua aktor atau pihak yang berusaha memperoleh sumber daya yang langka pada saat yang bersamaan. Karena itu paling tidak terdapat tiga komponen penting dalam konflik, yaitu tindakan (action), kontradiksi (incompatibility) dan aktor (actors). Hal ini senada dengan argumen Dahlerup (2002) bahwa distribusi sumber kekuasaan yang langka dan tidak merata menjadi salah satu sumber dasar terjadinya konflik. Menurut Levien (2000) seseorang atau kelompok dapat terlibat dalam konflik dilaterbelakangi oleh dua faktor. Pertama, adanya anggapan bahwa kebutuhan dan tujuan dari pihak yang berkonflik akan direalisasikan melalui konflik. Kedua, pihak yang berkonflik merasa bahwa kebutuhan antara pihak yang berkonflik tidaklah sama.

Fisher et al., (2001: 7-8) memaparkan lebih detail teori penyebab konflik yang terjadi di tengah masyarakat. Pertama, teori hubungan dalam masyarakat, yaitu konflik yang terjadi karena adanya ketidakpercayaan, polarisasi, dan permusuhan diantara individu maupun kelompok. Kedua, teori negosiasi prinsip, yaitu konflik yang diakibatkan oleh adanya perbedaan pandangan diantara orang yang terlibat dalam konflik. Ketiga, teori kebutuhan manusia, yaitu konflik yang muncul karena adanya perebutan terhadap kebutuhan dasar manusia yang langka. Ketika kebutuhan suatu kelompok tidak terpenuhi maka akan memicu konflik. Keempat, teori identitas, yaitu konflik yang muncul karena adanya perasaan identitas yang hilang atau memudar dari sebuah tatanan sosial. Kelima, teori transformasi konflik, yaitu konflik yang muncul 
karena adanya masalah ketidakadilan dan ketidaksertaraan dalam berbagai aspek kehidupan mencakup ekonomi, sosial, politik, dan kebudayaan sehingga menimbulkan kesenjangan.

Dalam konteks politik, kekuasaan menjadi salah satu sumber daya yang terbatas dimana hanya segelintir individu atau kelompok yang akan memegang kekuasaan. Karena itu, kekuasaan selalu berkaitan dengan dua komponen yaitu orang yang berkuasa dan orang yang dikuasai. Pakulski (2018) menyebut bahwa orang yang berkuasa lebih sedikit dibandingkan orang yang dikuasai. Karena kekuasaan yang terbatas sementara banyak pihak yang memperebutkan, maka kekuasaan rawan menjadi sumber konflik. Logika ini relevan jika dikaitkan dalam pemilu, sebab pemilu adalah mekanisme mengatur perebutan dan pergantian kekuasaan yang dilembagakan.

Konflik dalam pemilu secara institusional didesain sedemikian rupa untuk menjamin berjalannya prinsip free and fair dalam pemilu. Pihak atau kandidat yang merasa dirugikan selama proses pemilu dapat mengajukan sengketa untuk merebut hak-hak politiknya. Dalam konteks pemilu, sengketa adalah bagian dari konflik sebab adanya pertentangan kepentingan dari berbagai aktor yang berbeda. Oleh karena itu, seni dalam mengelola konflik atau sengketa dalam pemilu menjadi penting. Lembaga penyelenggara pemilu (KPU, Bawaslu, DKPP) atau lembaga yudisial (Mahkamah Agung, Mahkamah Konstitusi) bertanggungjawab untuk memiliki keterampilan dalam mencari solusi atau jalan keluar dalam menangani konflik dalam pemilu.

Upaya dalam menemukan jalan keluar untuk mengatasi konflik atau sengketa dalam pemilu adalah bagian dari diskursurs mengenai resolusi konflik (conflict resolution). Wallensteen (2018: 8) memahami resolusi konflik sebagai situasi di mana pihak-pihak yang berkonflik mengadakan perjanjian yang menyelesaikan perdebatan diantara mereka, saling menerima keberadaan satu sama lain dan menghentikan semua tindakan kekerasan terhadap satu sama lain. Setarikan nafas dengan Nicholson \& Wallensteen (1991: 59; 2018) menempatkan resolusi konflik sebagai proses yang memfasilitasi solusi di mana para pelaku yang berkonflik tidak lagi merasa perlu untuk terlibat dalam kegiatan konflik dan merasa bahwa distribusi manfaat dalam sistem sosial dapat diterima. Dari pendapat dua ahli ini dapat dilihat bahwa resolusi konflik adalah sesuatu yang perlu muncul setelah konflik.

Rahmadi (2010: 12-20) merumuskan beberapa bentuk resolusi konflik antara lain: pertama, Negosiasi, yaitu penyelesaian konflik dimana semua pihak berunding, berdiskusi dan berdebat secara langsung dan setara tanpa adanya pihak yang mendominasi pihak lain untuk mencapai konsensus bersama. Negosiasi dilakukan tanpa adanya bantuan atau intervensi dari pihak lain. Kedua, Mediasi, yaitu suatu penyelesaian konflik atau sengketa untuk mencari kesepatakan diantara pihak yang bertikai dengan menghadirkan bantuan dari pihak atau lembaga ketiga yang netral dan dianggap memiliki pengetahuan dan keahlian khusus terkait permasalahan yang dihadapi oleh 
pihak yang berkonflik. Pendapat, nasihat atau masukan dari mediator tidak mengikat karena ia hanya berperan sebagai fasilitator.

Ketiga, Arbitrasi, yaitu strategi penyelesaian konflik dengan meminta bantuan pada pihak ketiga yang dianggap netral yang memiliki kewenangan untuk memutuskan. Hasil dari keputusan dikeluarkan oleh piha ketiga ini dapat bersifat mengikat maupun tidak mengikat. Pemilihan pihak yang menjadi arbitrator berdasarkan pada kesepakatan bersama diantara pihak yang berkonflik. Keempat, Adjudikasi yaitu penyelesian sengketa atau konflik di pengadilan. Pihak yang merasa dirugikan mengajukan gugutan ke lembaga pengadilan. Keputusan dari lembaga pengadilan ini bersifat mengikat sedangkan pihak yang berkonflik tidak memiliki kewenangan untuk memilih hakim yang akan memutuskan perkara.

Menurut Surbakti, Supriyanto, \& Santoso (2011)) membagi lima jenis sengketa hukum dan pelanggaran pemilu yaitu: pertama, pelanggaran pidana pemilu yaitu pelanggaran terhadap ketentuan pidana Pemilu yang diatur dalam Undang-Undang ini yang penyelesaiannya dilaksanakan melalui pengadilan dalam lingkungan peradilan umum. Kedua, sengketa dalam proses pemilu yaitu sengketa yang ditangani oleh lembaga pengawas pemilu (Bawaslu atau Panwaslu) terkait dengan adanya ketidakpuasan salah satu pihak yang merasa dirugikan melalui keputusan yang dikeluarkan oleh KPU. Ketiga, pelanggaran administrasi pemilu yaitu pelanggaran pemilu yang bukan merupakan ketentuan pidana pemilu, melainkan pelanggaran yang sifatnya lebih pada hal teknis atau administratif.

Keempat, pelanggaran kode etik penyelenggara pemilu yaitu pelanggaran kode etik atau moral yang dilakukan oleh penyelenggara pemilu dalam menjalankan tugasnya melaksanakan penyelenggaraan pemilu berasarkan dengan prinsip, asas, dan nilai yang ditetapkan oleh peraturan. Kelima, perselisihan atau sengketa hasil pemilu yang diselesikan di Mahkamah Konstritusi (MK). Hasil keputusan dari MK bersifat final dan mengikat dan KPU wajib menindaklanjuti putusan MK. Undang Nomor 7 tahun 2017 tentang Pemilu mengatur bahwa dalam hal terjadi perselisihan penetapan perolehan suara hasil Pemilu, Pasangan Calon dapat mengajukan keberatan kepada Mahkamah Konstitusi dalam waktu paling lama 3 (tiga) hari setelah penetapan hasil Pemilu oleh KPU. Terakhir, sengketa hukum lainnya.

Tulisan ini secara spesifik akan menyoroti dua jenis sengketa pemilu yaitu sengketa proses pemilu dan sengketa kode etik penyelenggara pemilu. Sengketa proses pemilu yang dimaksud adalah sengketa antara bakal calon perseorangan menggugat KPU Kabupaten Lebak perihal keputusan KPU Kabupaten Lebak yang menyatakan gugurnya bakal calon perseorangan karena dinilai tidak memenuhi syarat dukungan. Sementara sengketa kode etik pemilu adalah terkait dengan anggota Komisioner KPU Kabupaten Lebak dengan DKPP yang berujung pada dikeluarkannya keputusan DKPP yang memberikan sanksi administratif kepada anggota Komisioner KPU Kabupaten 
Lebak karena dinilai kurang profesional dalam menangani proses pendaftaran bakal calon perseorangan.

\section{Eksistensi Calon Perseorangan Pada Pilkada Lebak}

Tahun 2018 menjadi salah satu pesta demokrasi di tingkat lokal yang ditandai dengan dilaksanakannya Pilkada Serentak di 171 daerah terdiri dari 17 provinsi, 39 kota dan 115 kabupaten melalui sistem pemilihan secara langsung. Masyarakat memiliki hak politik untuk menentukan calon kandidat. Pilkada Lebak menjadi salah satu daerah di Provinsi Banten yang menyelenggaran pemilihan calon bupati dan wakil bupati Kabupaten Lebak di tahun 2018. Namun Pilkada di Kabupaten Lebak hanya diikuti oleh calon tunggal. Akibatnya kontestasi elektoral bersifat semu karena hanya mengkontestasikan antara pasangan calon tunggal melawan kotak kosong.

Pada dasarnya, pemilu di daerah yang memiliki calon tunggal melawan kotak kosong sejatinya tidak benar-benar berada dalam payung kontestasi politik yang sesungguhnya. Dominasi kekuasaan dan hegemoni calon incumbent yang ditopang oleh modal ekonomi dan politik yang besar membuat partai berbondong-bondong mengusung calon incumbent tanpa memunculkan calon alternatif untuk berlaga dalam panggung pilkada (Bawaslu, 2018). Begitupula, calon independen yang difasilitasi oleh regulasi dengan membuka kesempatan menjadi calon kandidat tanpa harus memperoleh dukungan partai, juga tidak mempunyai modal yang cukup untuk melawan calon incumbent. Partai dan elit politik sebagai aktor rasional tentu tidak akan membuang tenaga dan biaya yang sia-sia tanpa didasari kalkulasi kemungkinan menang dalam kontetasi politik. Akibatnya calon tunggal tidak memiliki hambatan yang berarti dalam dimensi persaingan dengan aktor lain dalam berebut kekuasaan apalagi bersaing dengan kotak kosong (Lay, 2017).

Pilkada Kabupaten Lebak tahun 2018 mengkontestasikan antara pasangan calon tunggal yaitu Iti Octavia Jayabaya dan Ade Sumardi melawan kotak kosong. Iti Octavia Jayabaya merupakan calon incumbent yang sebelumnya menjabat sebagai bupati Lebak. la merupakan putri dari Mulyadi Jayabaya yang juga pernah menjabat sebagai bupati Lebak selama dua periode (2003-2013). Sementara Ade Sumardi merupakan calon incumbent yang sebelumnya menjadi wakil bupati Lebak periode 2013-2018 mendampingi Iti Octavia Jayabaya. Proses rotasi kepemimpinan yang hanya berkelindan di keluarga Jayabaya pada akhirnya membentuk dinasti politik Jayabaya. Kumunculan calon tunggal pada Pilkada Lebak tahun 2018 dapat dibaca sebagai hadirnya dominasi keluarga Jayabaya sebagai orang kuat lokal (local strongmen) yang menguasi panggung politik lokal dengan modal politik dan ekonomi yang besar disertai jejaring patronase yang memadai dalam relasi antar elit maupun dengan masyarakat (Nur'aini, 2018). Kondisi ini didukung oleh kegagalan partai politik dalam menjalankan fungsi rekrutmen politik dan pragmatisme partai dalam merespon dinamika politik elektoral sehingga tidak ada calon alternatif yang diusung oleh partai (Romli, 2018). 
Meskipun demikian, sebelum KPU Kabupaten Lebak secara sah menetapkan bahwa hanya ada satu pasangan calon yang mengikuti kontestasi elektoral, sebenarnya ada potensi bakal calon yang maju dari jalur perseorangan. Hanya saja dalam proses perjalanan pada masa sebelum pemilu (pra election), bakal calon perseorangan gugur terlebih dahulu sebelum berperang di medan pemilu karena dinyatakan tidak memenuhi syarat dukungan. Walau bagaimanapun, eksistensi calon perseorangan tetap menarik perhatian karena dibalik kegagalan mereka dalam kontestasi elektoral, terdapat konflik atau sengketa yang penting dibahas pada bagian ini.

Terdapat dua pasangan bakal calon dari jalur perseoragan yang berusaha menjadi bagian dari peserta pemilu pada Pilkada Lebak tahun 2018. Kedua pasangan tersebut yaitu Ahmad Jajuli-Sopiyan dan Cecep Sumarno-Didin Safrudin. Kedua bakal calon perseorangan ini telah melakukan safari politik ke berbagai partai untuk meraih dukungan. Namun, semua partai politik di wilayah Kabupaten Lebak serempak kembali mendukung incumbent yaitu pasangan Iti Octavia Jayabaya dan Ade Sumardi. Konsekuensinya, mereka kemudian memutuskan untuk berjuang melalui jalur perseorangan. Keputusan politik untuk maju di jalur perseorangan mewajibkan Ahmad Jajuli-Sopiyan dan Cecep Sumarno-Didin Safrudin harus bergerilya turun langsung ke masyarakat untuk mencari dukungan pemilih melalui pengumpulan fotokopi KTP. Berdasarkan keputusan KPU Kabupaten Lebak Nomor: 174/PI.03.2$\mathrm{Pu} / 3602 / K p u . K a b / X i / 2017$ tentang Penyerahan Syarat Dukungan Bakal Pasangan Calon Perseorangan Dalam Pemilihan Bupati Dan Wakil Bupati Lebak Tahun 2018 menyatakan bahwa jumlah dukungan fotokopi KTP untuk jalur perseorangan berjumlah 70.233 yang tersebar minimal di 15 kecamatan di Kabupaten Lebak.

Penyerahan syarat dukungan bakal pasangan calon dari jalur perseorangan ini dilakukan dalam dua bentuk, yaitu berbentuk hardcopy yang disususun berdasarkan desa atau kelurahan sesuai dengan kategori pengelompokkan kecamatan. Selain itu, persyaratan dukungan juga dalam bentuk softcopy dengan menggunakan form excel untuk selanjutnya diunggah ke dalam aplikasi Sistem Informasi Pencalonan (SILON). KPU Kabupaten Lebak sendiri sudah menetapkan jadwal terkait dengan penyerahan dukungan yaitu dimulai pada 25 sampai 29 November 2017 pukul 08.00 WIB-24.00 WIB. Kedua bakal pasangan calon yaitu Ahmad Jajuli-Sopiyan dan Cecep SumarnoDidin Safrudin mengklaim sudah memenuhi jumlah syarat minimal dukungan. Bakal pasangan calon Cecep Sumarno-Didin Safrudin mendaftarkan diri ke KPU Lebak pada tanggal 29 November pukul 23.30 WIB.

Tim Cecep Sumarno-Didin Safrudin mengklaim telah memiliki jumlah syarat dukungan sebanyak 71.111, melebihi batas minimal yang disyaratkan oleh KPU Kabupaten Lebak. Sementara, berkas pendaftaran bakal pasangan calon Ahmad JajuliSopiyan dinyatakan ditolak oleh KPU Kabupaten Lebak dengan alasan melebihi batas waktu pendaftaran sesuai dengan yang ditetapkan oleh KPU Lebak. Sebagaimana 
diketahui, bakal pasangan calon Ahmad Jajuli-Sopiyan datang ke KPU Lebak pada tanggal 29 November pukul 24.05 WIB yang berarti telah berganti hari. Selain itu, alasan KPU Lebak menolak berkas dukungan yang diserahkan oleh Ahmad JajuliSopiyan karena dianggap tidak memenuhi syarat pencalonan. Hal tersebut senada dengan keterangan dari Ketua Divisi Teknis Pencalonan KPU Lebak: "Kita tolak atau kita kembalikan, karena data yang ditunjukkan oleh pasangan pada berkas B.1-KWK juga kosong dan data yang di Silon juga kosang, nilainya masih nol" (Radarbanten.co.id, 2017). Merespon keputusan KPU Lebak, Ahmad Jajuli-Sopiyan mengajukan gugutan ke Bawaslu karena merasa dirugikan dengan keputusan KPU Lebak.

\section{Dinamika dan Polemik Sengketa Calon Perseorangan}

Ditolaknya berkas administrasi persyaratan bakal calon perseorangan milik Ahmad Jajuli-Sopiyan oleh KPU Kabupaten Lebak membuat pihak Ahmad JajuliSopiyan merasa kecewa dan dirugikan dengan keputusan KPU Kabupaten Lebak. Pihak Ahmad Jajuli-Sopiyan mengklaim bahwa semua berkas persyaratan sudah dipenuhi sesuai dengan prosedur hukum yang berlaku. Akhirnya, Ahmad Jajuli-Sopiyan melakukan gugatan ke Bawaslu Kabupaten Lebak terkait sengketa pendaftaran bakal calon perseorangan. Di sisi lain, berkas syarat pendaftaran yang telah dikumpulkan oleh bakal pasangan calon milik Cecep Sumarno-Didin Safrudin juga dinyatakan ditolak oleh KPU Kabupaten Lebak setelah diperiksa kelengkapan persyaratan dukungan. Sehingga KPU Kebupaten Lebak mengeluarkan keputusan bahwa kedua bakal pasangan calon dari jalur perseorangan baik Ahmad Jajuli-Sopiyan maupun Cecep Sumarno-Didin Safrudin sama-sama tidak memenuhi syarat dukungan.

Pihak Cecep Sumarno-Didin Safrudin mengambil langkah yang sama dengan Ahmad Jajuli-Sopiyan yaitu mengajukan gugatan ke Bawaslu Kabupaten Lebak. Implikasinya, Bawaslu Kabupaten Lebak menerima dua laporan permohonan dengan kasus yang sama yaitu terkait keberatan atas keputusan KPU Kabupeten Lebak terkait penetapan bakal pasangan calon jalur perseorangan. Kedua bakal pasangan calon jalur perseorangan menggugat KPU Kabupaten Lebak dengan tuduhan bahwa KPU Kabupaten Lebak tidak profesional dalam melakukan pemeriksaan berkas persyaratan dukungan fotocopy KTP sehingga menyebabkan mereka dinyatakan tidak memenuhi persyaratan.

Bawaslu Kabupaten Lebak dalam mengelola sengketa terlebih dahulu mengedepankan aspek musyawarah dimana pihak Pemohon dalam hal ini bakal pasangan calon perseorangan dan pihak Termohon yaitu KPU Kabupaten Lebak didorong untuk musyawarah dan bertukar pendapat dengan menghadirkan saksi dan bukti-bukti yang meyakinkan. Sementara Bawaslu Kabupaten Lebak lebih banyak berperan sebagai pihak yang mendengarkan pemaparan dari masing-masing pihak yang bersengketa. Apabila proses musyawarah tidak bisa ditemukan jalan keluar, maka langkah selanjutnya akan dinaikkan pada tingkat yang lebih serius yaitu upaya 
mediasi dan adjudikasi. Sayangnya, dalam proses persidangan di Bawaslu, pihak dari Ahmad Jajuli-Sopiyan tidak menghadiri persidangan di Bawaslu sebanyak dua kali secara berturut-turut. Hal ini yang menyebabkan guguatan dari pihak Ahmad JajuliSopiyan dinyatakan gugur oleh Bawaslu Kabupaten Lebak (Radarbanten.co.id, 2017). Keputusan Bawaslu ini terlegitimasi sebagaimana tertuang dalam Peraturan Bawaslu Nomor 15 tahun 2017 Pasal 21 bahwa apabila pemohon dua kali tidak menghadiri sidang sengketa maka dinyatakan gugur.

Sementara, proses sidang sengketa pihak Cecep Sumarno-Didin Safrudin masih berlanjut di Bawaslu Kabupaten Lebak. Untuk diketahui, proses penyelesian sidang sengketa melalui musyawarah ini sudah dilakukan sejak tanggal 11 Desember 2017. Meskipun demikian, antara Pemohon dan Termohon belum menemukan kata mufakat. Masing-masing pihak masih bertahan dengan argumennya masing-masing. Pihak Cecep Sumarno-Didin Safrudin menilai bahwa KPU Kabupaten Lebak tidak profesional dan teliti dalam memeriksa dan menghitung berkas syarat dukungan. Sedangkan pihak KPU Kabupaten Lebak masih komitmen dengan pendiriannya bahwa bakal pasangan calon Cecep Sumarno-Didin Safrudin tidak memenuhi syarat dukungan minimal yaitu sebanyak 70.000 dukungan. Akibatnya, proses persidangan menemukan jalan buntu (Titiknol.co.id, 2017). Oleh karena itu, keputusan sidang akan diputuskan oleh Bawaslu Kabupaten Lebak sebab belum ada mufakat diantara kedua belah pihak. Bawaslu Kabupaten Lebak sebagai pimpinan sidang akan mengambil keputusan berdasarkan pada keterangan para saksi dan bukti-bukti yang dimiliki oleh kedua belah pihak (Pemohon dan Termohon) sesuai dengan yang ada di persidangan.

Proses persidangan di Bawaslu Kabupaten Lebak kurang lebih memakan waktu 6 hari untuk menentukan hasil sidang sengketa. Pada tanggal 16 Desember 2017, Bawaslu Kabupaten Lebak mengabulkan permohonan bakal calon dari jalur perseorangan Cecep Sumarno-Didin Saprudin. Bawaslu Kabupaten Lebak memerintahkan kepada KPU Kabupaten Lebak untuk melakukan penghitungan ulang berkas formulir dukungan bakal pasangan calon milik Cecep Sumarno-Didin Saprudin. Proses penghitungan kembali ini dilakukan paling lambat dalam waktu tiga hari kerja setelah putusan sidang dikeluarkan oleh Bawaslu Kabupaten Lebak (Chanelbanten.com, 2017). Meskipun demikian, setelah putusan Bawaslu dikeluarkan, ternyata KPU Kabupaten Lebak tidak dengan segera menjalankan dan menindaklanjuti putusan dari Bawaslu Kabupaten Lebak. Hal tersebut membuat bakal pasangan calon Cecep Sumarno-Didin Saprudin kembali mengajukan permohonan kepada Bawaslu Kabupaten Lebak. Tidak hanya itu, Cecep Sumarno-Didin Saprudin juga melaporkan permohonan kepada DKPP terkait dengan aduan pelanggaran kode ektik penyelenggra pemilu bahwa KPU Kabupaten Lebak tidak profesional sebagai lembaga yang menjalankan pelaksanaan pemilu (Mediabanten.com, 2017).

Gugatan ke dua ke Bawaslu Kabupaten Lebak kembali memenangkan pihak Pemohon yaitu Cecep Sumarno-Didin Saprudin. Bawaslu Kabupaten Lebak dalam 
putusan penyelesaian sengketa Pilkada Lebak yang tertuang dalam Surat Keputusan Nomor 03/PS.Pilkada/Panwaslu/LBK/I/2018 pada tanggal 23 Januari 2018 menyebutkan paling tidak ada empat point: pertama, membatalkan Surat Keputusan KPU Kabupaten Lebak terkait dengan penatapan bakal pasangan calon bupati dan wakil bupati dari jalur perseorangan atas nama Cecep Sumarno-Didin Saprudin yang menyatakan bahwa Cecep Sumarno-Didin Saprudin tidak memenuhi syarat dukungan minimal. Kedua, memerintahkan kepada KPU Kabupaten Lebak untuk menertibkan Surat Keputusan terkait penetapan pasangan calon bupati dan wakil bupati Kabupaten Lebak dari jalur perseorangan atas nama Cecep Sumarno-Didin Saprudin bahwa Cecep Sumarno-Didin Saprudin telah memenuhi syarat dukungan minimal sejumlah 77.642 berdasarkan pada BA Nomor. 05/PL.03.2-BA/3602/KPU-Kab/I2018. Angka 3 huruf b Tanggal 06 Janauri 2018.

Ketiga, memerintahkan kepada KPU Kabupaten Lebak untuk mengikutsertakan pemohon dalam hal ini tim Cecep Sumarno-Didin Saprudin dalam tahapan verifikasi administrasi calon persorangan dan tahapan selanjutnya. Hal ini tidak lepas dari adanya temuan bahwa pada saat verifikasi administrasi awal, KPU Kabupaten Lebak tidak mengikutsertakan pihak Cecep Sumarno-Didin Saprudin. Ihwal ini yang kemudian menjadi pemicu awal terjadinya sengketa di Bawaslu Kabupaten Lebak. Selain itu, putusan Bawaslu Kabupaten Lebak juga memerintahkan kepada KPU Kabupaten Lebak untuk membuat jadwal dan tahapan susulan. Hal ini disebabkan adanya proses persidangan sengketa sehingga berdampak pada jadwal tahapan pemilu yang sudah dibuat sebelumnya. Keempat, Bawaslu Kabupaten Lebak memerintahkan kepada KPU Kabupaten Lebak untuk menindaklanjuti keputusan tersebut paling lambat tiga hari kerja setelah keputusan tersebut dikeluarkan.

Setelah KPU Kabupaten Lebak meinindaklanjuti putusan Bawaslu Kabupaten Lebak dan melakukan kembali verfikasi dokumen syarat dukungan bakal pasangan calon Cecep Sumarno-Didin Saprudin, akhirnya KPU Kabupaten Lebak menyatakan bahwa bakal pasangan calon dari jalur perseorangan atas nama Cecep Sumarno-Didin Saprudin dinyatakan memenuhi syarat. Hal tersebut sebagaimana tertuang dalam Surat Keputusan dengan nomor 19/HK.03/1-Kpt/3602/KPU-Kab/I/2018 yang ditetapkan pada tanggal 25 Januari 2018 dan ditandatangi oleh Ketua KPU Kabupaten Lebak, Ahmad Saparudin (Mediabanten.com, 2018). Meskipun demikian, perjalanan Cecep Sumarno-Didin Saprudin berlum berakhir sebab masih ada proses dan tahapan pemilu lainnya yang harus dilewati mengingat keputusan KPU Kabupaten Lebak tersebut hanya sebatas pada penetapan syarat dukungan melalui verifikasi bukti fisik.

Dengan kata lain, Cecep Sumarno-Didin Saprudin harus melalui tahapan verifikasi faktual yang dilakukan oleh KPU Kabupaten Lebak sebelum kemudian dinyatakan secara sah menjadi pasangan calon bupati dan wakil bupati pada Pilkada Kabupaten Lebak. Verifikasi faktual adalah kegiatan mencocokkan dokumen fotokopi dukungan yang telah diterima oleh KPU Kabupaten Lebak dengan data sesungguhnya 
di lapangan. Hal ini untuk menguji keakuratan dan kebenaran bukti dokumen dukungan serta untuk meminimalisir potensi terjadinya manipulasi dukungan yang dilakukan oleh tim Cecep Sumarno-Didin Saprudin.

\section{Sengketa Kode Etik di DKPP: Sanksi untuk KPU Lebak}

Di sela-sela proses verifikasi faktual, sebagaimana telah disinggung sebelumnya, Cecep Sumarno-Didin Saprudin juga melaporkan permohonan kepada DKPP terkait dengan aduan bahwa KPU Kabupaten Lebak tidak profesional dalam kapasitasnya sebagai lembaga penyelenggara pemilu khususnya terkait dengan penghitungan dan verfikiasi dokumen fisik syarat dukungan bakal calon perseorangan yang menyebabkan Cecep Sumarno-Didin Saprudin merasa dirugikan karena KPU Kebupaten Lebak mengeluarkan surat keputusan bahwa Cecep Sumarno-Didin Saprudin tidak memenuhi syarat dukungan. DKPP memiliki wewenang dalam menyelesaikan permohonan tersebut karena fungsi lembaga ini sebagai pengawas kote etik lembaga penyelenggara pemilu.

Dalam permohonan tersebut, Cecep Sumarno-Didin Saprudin mengajukan gugutan secara tertulis ke DKPP pada tanggal 26 Januari 2018 dan 9 Februari 2018 dengan menyampaikan empat pokok aduan (Dkpp.go.id, 2018) : pertama, pada tanggal 29 November 2017 KPU Kabupaten Lebak tidak mau menandatangani tanda terima dari Pengadu, sebagai bukti bahwa Pengadu telah menyerahkan dokumendokumen yang merupakan persyaratan wajib untuk menjadi bakal calon Bupati dan Wakil Bupati Kabupaten Lebak. Selain itu KPU Kabupaten Lebak dalam melaksanakan proses verifikasi jumlah minimal dukungan dan sebaran berlangsung tidak tertib dan rapi dengan tidak memakai seragam, ruangan dimana berlangsungnya proses verifikasi tidak steril dan siapapun bisa masuk, pintu kantor tidak dikunci dan dijaga ketat dan Para Teradu tidak membuat catatan tertulis dalam verifikasi serta banyak tumpukan berkas yang berantakan dan berserakan dimana kemudian tidak adanya pembagian meja yang jelas untuk Pengadu dan Para Teradu.

Kedua, KPU Kabupaten Lebak melakukan verifikasi jumlah minimal dukungan dan sebaran tidak profesional serta KPU Kabupaten Lebak telah salah dalam melakukan verifikasi jumlah minimal dukungan dan sebaran. Ketiga, pada tanggal 1 Desember 2017 KPU Kabupaten Lebak salah dalam mengeluarkan penetapan hasil verifikasi jumlah minimal dukungan dan sebaran terhadap Pengadu tidak memenuhi syarat, sehingga Pengadu tidak memenuhi syarat sebagai bakal pasangan calon Bupati dan Wakil Bupati Kabupaten Lebak tahun 2018. Keempat, KPU Kabupaten Lebak tidak melaksanakan isi Putusan Penyelesaian Sengketa Pemilihan Bupati dan Wakil Bupati Kabupaten Lebak Nomor Register Permohonan : 01/PS.Pilkada/Panwaslu-LBK/XII/2017.

Dalam proses persidangan di DKPP, KPU Kabupaten Lebak sebagai pihak teradu menyanggah pokok aduan yang diajukan oleh tim Cecep Sumarno-Didin Saprudin. Dari sudut pandang KPU Kabupaten Lebak bahwa: pertama, KPU Kabupaten Lebak telah 
menunjuk petugas khusus KPU untuk menerima dan menghitung berkas syarat dukungan milik Cecep Sumarno-Didin Saprudin dan ruangan verifikasi telah dijaga secara ketat oleh pihak kepolisian sehingga proses verifikasi steril dan aman. Hal ini membantah pihak Pengadu yang mengklaim bahwa KPU Kabupaten Lebak tidak menerima tanda terima dan ruang verifikasi tidak steril. Kedua, KPU tetap melaksanakan putusan Bawaslu Kabupaten Lebak untuk melakukan verifikasi administrasi dokumen milik Cecep Sumarno-Didin Saprudin. KPU juga membantah aduan dari Pengadu bahwa KPU tidak profesional. Berdasarkan keterangan KPU, seluruh proses pendaftaran bakal pasangan calon termasuk dari jalur perseorangan sudah sesuai dengan prosedur, standar, dan aturan yang berlaku ( Dkpp.go.id, 2018).

DKPP sebagai lembaga yang memimpin persidangan menghadirkan semua pihak yang terkait dengan sengketa ini berserta para saksi yaitu pihak pengadu dalam hal ini Cecep Sumarno-Didin Saprudin dan saksi, pihak teradu dalam hal ini KPU Kabupaten Lebak, dan pihak Bawaslu Kabupaten Lebak sebagai lembaga pengawas pemilu, Pihak KPU Provinsi Banten sebagai lembaga penyelenggara pemilu di tingkat provinsi yang dalam kasus sengketa ini kapasitasnya sebagai institusi yang membawahi KPU Kabupaten Lebak terkait dengan fungsi koordinasi dan konsultasi mengani penanganan sengketa calon perseorangan. Semua pihak tersebut dimintai keterangan disertai dengan alat bukti yang dapat memperkuat dan mendukung argumen dari masing-masing pihak.

Setelah melalui proses persidangan sengketa kode etik, pada tanggal 19 Maret 2018, DKPP mengeluarkan surat keputusan Nomor: 15/DKPP-PKE-VII/2018t. Terdapat empat pokok dalam surat keputusan tersebut. Pertama, mengabulkan pengaduan Pengadu untuk sebagian. Kedua, Menjatuhkan sanksi berupa Peringatan kepada Teradu yaitu Komisioner KPU Kabupaten Lebak. Ketiga, Memerintahkan KPU Provinsi Banten untuk melaksanakan Putusan tersebut paling lama 7 (tujuh) hari sejak dibacakan. Keempat, Memerintahkan Badan Pengawas Pemilu Republik Indonesia untuk mengawasi pelaksanaan Putusan ini ( Dkpp.go.id, 2018). Dari putusan DKPP tersebut dapat dikatakan bahwa pihak Cecep Sumarno-Didin Saprudin memenangkan persidangan sebab sebagian dari materi aduan dikabulkan oleh DKPP. Artinya, berdasarkan keputusan DKPP, KPU Kabupaten Lebak dinilai terbukti melanggar kode etik dalam hal kurang profesional dan teliti dalam melaksanakan proses verifikasi persyaratan dukungan bakal calon perseorangan meskipun dengan tingkat pelanggaran kecil.

\section{Episode Akhir Perjuangan Calon Perseorangan}

Meskipun pihak Cecep Sumarno-Didin Saprudin memenangkan gugutan kode etik di DKPP, tetapi perjuangan sengketa di Bawaslu Kabupaten Lebak nampaknya menemukan jalan terjal. Setelah Bawaslu Kabupaten Lebak menyatakan bahwa KPU Kabupaten Lebak harus meneruskan proses verifikasi syarat dukungan bakal calon 
perseorangan, namun pihak Cecep Sumarno-Didin Saprudin kembali mengajukan gugutan ke Bawaslu Kabupaten Lebak sebab pada saat proses verifikasi faktual di lapangan, KPU Kabupaten Lebak menemukan ketidakcocokkan antara bukti fisik dukungan dengan yang ditemukan di lapangan. Pihak Cecep Sumarno-Didin Saprudin masih dengan laporan yang sama bahwa KPU Kabupaten Lebak dianggap tidak profesional.

Persidangan sengketa bakal pasangan calon perseorangan diselenggarakan di kantor Bawaslu Lebak. Pada tanggal 3 Maret 2018, Bawaslu mengeluarkan keputusan akhir yang langsung dibacakan oleh Ketua Panwaslu Lebak Ade Jurkoni dengan disaksikan oleh Ketua KPU Lebak, Ahmad Saprudin dan anggota komisioner lainnya (Termohon) serta Cecep Sumarno-Didin Saprudin sebagai bakal pasangan calon perseorangan (Pemohon). Bawaslu Kabupaten Lebak memutuskan menolak gugutan bakal pasangan calon perseorangan Cecep Sumarno-Didin Saprudin dengan pertimbangan bahwa berdasarkan keterangan yang diperoleh dari para saksi, pasangan Cecep Sumarno-Didin tidak memenuhi berkas persyaatan pencalonan untuk jalur perseorangan sebagaimana yang tertuang dalam keputusan PKPU nomor 3 tahun 2017 tentang pencalonan Bupati dan Wakil Bupati (Faktabanten.co.id, 2018). Dengan ditolaknya gugutan tersebut, maka Cecep Sumarno-Didin dinyatakan gugur dan tidak bisa melanjutkan ke tahapan pilkada berikutnya.

Kendati demikian, sebenarnya pihak Cecep Sumarno-Didin masih dapat mengajukan banding ke PTUN (Pengadilan Tata Usaha Negara) apabila keputusan dari Bawaslu Kabupaten Lebak dianggap merugikan. Tetapi pihak Cecep Sumarno-Didin tidak mengambil opsi tersebut. Implikasinya, kontestasi elektoral pada Pilkada Kabupaten Lebak tahun 2018 secara resmi hanya diikuti oleh satu pasangan calon yaitu Iti Octavia Jayabaya dan Ade Sumardi yang notabene-nya adalah calon incumbent dan didukung oleh semua partai politik yang ada di Lebak. Hal tersebut membuat langkah pasangan Iti Octavia Jayabaya dan Ade Sumardi memiliki peluang yang sangat besar untuk tampil sebagai pemenang karena hanya melawan kotak kosong. Hasil akhir perolehan suara Pilkada Lebak menunjukkan pasangan calon Iti Octavia Jayabaya-Ade Sumardi memperoleh suara sebanyak 453.938 (76.96\%) sedangkan kotak kosong hanya memperoleh 135.879 (23,04\%). Ini berarti pasangan Iti Octavia Jayabaya-Ade Sumardi secara sah terpilih kembali menjadi bupati dan wakil bupati untuk kedua kalinya.

\section{Adjudikasi Sebagai Pilihan Resolusi Konflik}

Berdasarkan ulasan yang telah dipaparkan pada pembahasan sebelumnya mengenai dinamika dan polemik sengketa calon perseorangan pada Pilkada Lebak tahun 2018, dapat dilihat bahwa subjek yang berkonflik adalah bakal calon perseorangan dan KPU Kabupaten Lebak. Adapun substansi permasalahan yang menjadi sumber konflik adalah terkait dengan persyaratan bakal calon jalur 
perseorangan. Konflik muncul lebih disebabkan karena adanya benturan kepentingan yang berbeda antara bakal calon perseorangan dan KPU Kabupaten Lebak. Dimana bakal calon perseorangan akan berusaha semaksimal mungkin agar dapat mengikuti kontestasi elektoral dengan menjadi calon kandidat. Namun di sisi lain, terdapat aturan main yang tertuang dalam regulasi pemilu untuk menentukan apakah seseorang layak untuk dinyatakan sebagai calon kandidat. KPU Kabupaten Lebak bertanggungjawab untuk memastikan bahwa siapa pun bakal calon yang mendaftar harus memenuhi persyaratan sesuai dengan aturan main.

Konflik hadir ketika KPU Kabupaten Lebak menyatakan bahwa berkas pendaftaran yang dikumpulkan oleh bakal calon perseorangan tidak memenuhi syarat dukungan. Sehingga secara tidak langung, KPU Kabupaten Lebak sudah menutup langkah bakal calon perseorangan untuk maju ke tahap selanjutnya. Adanya ketidakpuasan, kekecewaan dan merasa dirugikan atas keputusan KPU Lebak membuat bakal calon perseorangan mengajukan gugutan. Dari sinilah konflik terus berlanjut hingga ke tahap pengadilan di Bawaslu Kabupaten Lebak. Artinya, apabila bakal calon perseorangan merasa puas dengan keputusan KPU Kabupaten Lebak, maka tidak akan terjadi sengketa. Masalah dianggap selesai. Apabila mengacu pada pendapat Levien (2000) maka dalam konteks ini, sengketa antara bakal calon perseorangan dengan KPU Kabupaten Lebak dikarenakan sengketa dibutuhkan oleh bakal calon perseorangan karena dengan bersengketa ada peluang tujuan mereka akan tercapai yaitu maju ke tahapan selanjutnya dalam proses pemilu. Sebab apabila pihak bakal calon perseorangan tidak mengajukan sengketa maka saat itu pula perjuangan mereka terhenti.

Bawaslu Kabupaten Lebak menjadi aktor penting dalam menyelesaikan sengketa tersebut sebab substansi masalah yang disengketakan masuk pada bentuk sengketa proses pemilu. Dalam Undang-Undang Nomor 7 tahun 2017 memberi wewenang yang lebih besar kepada Bawaslu dibandingkan dengan sebelumnya, yaitu adanya kewenangan menjadi pengadil dalam memutus perkara kepemiluan khususnya terkait dengan Penyelesian Sengketa Proses Pemilu (PSPP). Pada UU tersebut di pasal 466 menyebut bahwa yang dimaksud sengketa proses adalah sengketa yang terjadi antara calon maupun peserta pemilu dengan keputusan KPU selaku penyelenggara pemilu. Artinya, peran Bawaslu di sini sangat sentral dalam menyelesaikan konflik antara bakal calon perseorangan dan KPU Kabupaten Lebak.

Ketika sebuah konflik sudah melibatkan pihak ketiga dalam hal ini Bawaslu Kabupaten Lebak, maka pilihan resolusi konflik sudah tidak memungkinkan untuk menggunakan jalur negosiasi. Sebab negosiasi adalah penyelesian konflik dilakukan oleh pihak yang berkonflik tanpa adanya bantuan atau intervensi dari pihak lain. Artinya, pilihan resolusi konflik yang mungkin adalah melalui jalur mediasi, arbitrasi atau adjudikasi. Dalam konteks sengketa antara bakal calon perseorangan dengan KPU 
Kabupaten Lebak, pilihan resolusi konflik lebih banyak menggunakan jalur adjudikasi yaitu penyelesian sengketa atau konflik di pengadilan.

Bawaslu berwenang menjadi hakim yang akan memutuskan perkara. Sebenarnya, sebelum ke tingkat adjudikasi, Bawaslu Kabupaten Lebak sudah mengadakan jalur mediasi melalui musyawarah untuk mufakat diantara pihak yang berkonflik karena bisa jadi konflik dikarenakan adanya perbedaan pendapat atau kesalahan teknis. Tetapi upaya tesebut tidak ampuh dalam meredam konflik sebab diantara kedua belah pihak saling berdebat dan tidak ada yang mau mengalah. Akhirnya, jalur adjudikasi menjadi pihan terakhir. Bawaslu Kabupaten Lebak dianggap sah dalam menjalankan fungsi pengadilan meskipun secara tata kelembagaan negara, Bawaslu bukan termasuk dalam lembaga pengadilan (yudisial). Mengutip pendapat Asshidiqie dalam Bawaslu.go.id (2019) bahwa Bawaslu dapat disebut sebagai lembaga quasi pengadilan, yaitu dapat menjalankan fungsi pengadilan terkait dengan memutuskan Penyelesian Sengketa Proses Pemilu (PSPP) meski bukan lembaga yudisial.

Konsekuensi dari pilihan adjudikasi sebagai resolusi konflik adalah pihak yang bersengketa harus menerima hasil keputusan Bawaslu Kabupaten Lebak sebab keputusan bersifat final dan mengikat. Meskipun ada pengecualian untuk sengketa calon atau peserta pemilu yaitu dapat mengajukan ke Pengadilan Tinggi Usaha Negara (PTUN) apabila keputusan Bawaslu tidak memuaskan. Dalam kasus sengketa Pilkada Lebak, bakal pasangan calon tidak melakukan banding ke PTUN, artinya keputusan Bawaslu Kabupaten Lebak yang menolak gugutan bakal pasangan calon perseorangan dianggap diterima.

\section{Penutup}

Sengketa pemilu antara bakal calon perseorangan dengan KPU Lebak terjadi karena adanya ketidakpuasan bakal calon perseorangan yaitu Cecep Sumarno-Didin Saprudin terkait keputusan KPU Kabupaten Lebak yang menolak berkas pendaftaran sebagai calon kandidat pada pemilihan Bupati dan Wakil Bupati tahun 2018 karena dianggap tidak memenuhi syarat dukungan minimal berupa fotokopi KTP elektronik dari masyarakat Lebak. Sengketa tersebut ditangani secara langsung oleh Bawaslu Kabupaten Lebak karena substansi sengketa masuk pada jenis sengketa proses pemilu. Sedangkan Resolusi konflik yang digunakan untuk mengatasi sengketa tersebut adalah dengan metode adjudikasi. Hal ini dipilih sebab pihak yang berkonflik tidak pernah menemui kesepakatan bersama ketika dihadapkan melalui proses musyawarah yang diselenggarakan oleh Bawaslu Kabupaten Lebak.

Dalam putusan hasil sengketa, bakal calon perseorangan kalah di persidangan sehingga langkah mereka untuk maju dalam kontestasi elektoral pada Pilkada Lebak terhenti. Kegagalan bakal calon perseorangan untuk tampil dalam pentas kontestasi elektoral mengonfirmasi temuan-temuan sebelumnya bahwa eksistensi calon perseorangan sebagai antitesa terhadap kekuasaan partai politik masih lemah. 
Padahal, semangat awal dibukanya peluang calon perseorangan tanpa dukungan partai adalah untuk memberi peluang politik yang lebar kepada masyarakat untuk memilih dan dipilih. Namun, calon perseorangan kerap menemukan kendala. Terutama dalam hal memenuhi syarat dukungan pencalonan.

\section{Ucapan terima kasih}

Penulis mengucapkan terima kasih kepada Bambang Eka Cahya Widodo \& Azka Abdi Amrurabbi yang telah memberi banyak masukan terhadap tulisan ini.

\section{Pendanaan}

Penulis tidak menerima bantuan pembiayaan untuk penelitian, kepenulisan (authorship), dan publikasi dari pihak manapun.

\section{Daftar Pustaka}

Aermadepa, A. (2019). Penyelesaian Sengketa Proses Pemilu Oleh Bawaslu, Tantangan Dan Masa Depan. JUSTITIA: Jurnal IImu Hukum Dan Humaniora, 1(2), 1-14.

Armunanto, A. A. (2015). Potensi Konflik pada Pemilihan Kepala Daerah Langsung di Kota Makassar Tahun 2013. The POLITICS: Jurnal Magister IImu Politik Universitas Hasanuddin, 1(1), 23-36.

Bawaslu.go.id. (2019). Upaya Cepat Bawaslu Dalam Penyelesaian Sengketa Proses Pemilu. Retrieved from https://bawaslu.go.id/id/berita/upaya-cepat-bawasludalam-penyelesaian-sengketa-proses-pemilu

Bawaslu. (2018). Fenomena Calon Tunggal, Studi Kasus Pada Pilkada 2018 di 16 Kabupaten/Kota. Jakarta: Bawaslu Republik Indonesia.

Chanelbanten.com. (2017). Panwaslu Kabulkan Permohonan Cecep Sumarno Disengketa Pilkada Lebak. Retrieved from https://www.chanelbanten.com/panwaslu-kabulkan-permohonan-cecepsumarno-disengketa-pilkada-lebak/

Cressey, D. R. (1950). The criminal Violation of Financial Trust. American Sociological Review, 15(6), 738-743.

Dahlerup, D. (2002). Menggunakan Kuota untuk Meningkatkan Representasi Politik Perempuan dalam Perempuan di Parlemen: Bukan Sekedar Jumlah. IDEA.

Devi, P. G. (2019). Sengketa Verifikasi Partai Politik pada Badan Pengawas Pemilihan Umum. Jurist-Diction, 2(5), 1787-1798.

Efriza, N. F. N. (2019). Eksistensi Partai Politik Dalam Persepsi Publik (The Existence of The Political Parties in Public Perception). Jurnal Politica Dinamika Masalah Politik Dalam Negeri Dan Hubungan Internasional, 10(1), 17-38.

Faktabanten.co.id. (2018). Panwaslu Lebak Tolak Gugatan Bakal Calon Perseorangan CSDS. Retrieved from https://faktabanten.co.id/blog/2018/03/03/panwaslu-lebaktolak-gugatan-bakal-calon-perseorangan-cs-ds/

Firdaus. (2014). Penyelesaian Sengketa Pemilu Sebagai Upaya Memulihkan Kepercayaan Dan Memperkuat Legitimasi Pemerintahan Demokrasi. Fiat Justitia, 8(2), 208-220.

Fisher, S., Abdi, D. I., Smith, R., Ludin, J., Williams, S., \& Williams, S. (2001). Mengelola Konflik: Keterampilan dan Strategi untuk Bertindak. Jakarta: The British Council. 
Katadata.co.id. (2019). Survei LSI, KPK Paling Dipercaya Rakyat, Parpol Rendah. Retrieved from https://katadata.co.id/berita/2019/08/29/survei-lsi-kpk-palingdipercaya-rakyat-parpol-terendah

Keadilan, D., Kehormatan, D. A. N., \& Pemilu, P. (2018). Salinan Putusan Dewan Kehormatan Penyelenggara Pemilu.

Lay, C. (2017). Tautan Politik antara Pengrajin Batik, Parlemen, dan Masyarakat Sipil di Yogyakarta. Prisma Jurnal, 36(1), 83-99.

Levien, M. (2000). pecial Economic Zone and Accumulation by Dispossession. Journal of Agrarian Change, 11, 454-483.

Lowery, D., van Witteloostuijn, A., Peli, G., Brasher, H., Otjes, S., \& Gherghina, S. (2013). Policy Agendas and Births and Deaths of Political Parties. Party Politics, 19(3), 381407.

Mediabanten.com. (2017). Ketua Bawaslu Banten: KPU Lebak Abaikan Putusan Panwaslu Soal Cecep-Didin. Retrieved from https://mediabanten.com/ketuabawaslu-banten-kpu-lebak-abaikan-putusan-panwaslu-soal-cecep-didin/

Mediabanten.com. (2018). KPU Lebak Terbitkan SK Penetapan Bapaslon Cecep-Didin Penuhi Syarat.

Nicholson, M. (1991). Resolution: The Role of Rational Approaches and Their Criticism. New Directions in Conflict Theory: Conflict Resolution and Conflict Transformation, 57.

Pakulski, J. (2018). Classical Elite theory: Pareto and Weber. In The Palgrave Handbook of Political Elites (pp. 17-24). Springer.

Pratikno, P. (2007). Calon Independery Kualitas Pilkada dan Pelembagaan Parpol. Jurnal IImu Sosial Dan IImu Politik, 10(3), 37712.

Radarbanten.co.id. (2017). Daftar Jalur Perseorangan Bakal Paslon Ini Ditolak KPU Lebak. Retrieved from https://www.radarbanten.co.id/daftar-jalur-perseorangan-bakalpaslon-ini-ditolak-kpu-lebak/

Rahmadi, T. (2010). Mediasi: Penyelesaian Sengketa Melalui Pendekatan Mufakat. Rajawali Pers.

Ramadlan, M. F. S., \& Wahyudi, T. H. (2016). Pembiaran pada Potensi Konflik dan Kontestasi Semu Pemilukada Kota Blitar: Analisis Institusionalisme Pilihan Rasional. Politik Indonesia: Indonesian Political Science Review, 1(2), 136-153.

Robison, R., \& Hadiz, V. R. (2004). Reorganising Power in Indonesia: The Politics of Oligarchy in an Age of Markets (Vol. 3). Psychology Press.

Romli, L. (2018). Pilkada Langsung, Calon Tunggal, dan Masa Depan Demokrasi Lokal. Jurnal Penelitian Politik, 15(2), 143-160.

Roth, D. (2009). Studi Pemilu Empiris: Sumber, Teori-teori, Instrumen dan Metode (terj). (D. Ambardi, Ed.). Jakarta: Friedrich Naumann Stiftung dan LSI.

Santoso, P. (2018). Lokalitas Sebagai Konteks untuk Berdemokrasi. In P. Santoso, L. N. Bayo, \& W. P. Samadhi (Eds.), Rezim Lokal di Indonesia: Memaknai Ulang Demokrasi Kita. Jakarta: Yayasan Obor Indonesia. Yogyakarta: Yayasan Obor Indonesia.

Slater, D. (2004). Indonesia's Accountability Trap: Party Cartels and Presidential Power After Democratic Transition. Indonesia, (78), 61-92.

Surbakti, R., Supriyanto, D., \& Santoso, T. (2011). Penanganan Pelanggaran Pemilu. 
Mahpudin I Konflik Pemilu: Dinamika Sengketa Calon Perseorangan dalam Kontestasi Elektoral...

Kemitraan bagi Pembaruan Tata Pemerintahan.

Titiknol.co.id. (2017). Musyawarah Putusan Panwaslu Lebak Temui Jalan Buntu.

Retrieved from https://titiknol.co.id/politik/musyawarah-putusan-panwaslulebak-temui-jalan-buntu/

Wallensteen, P. (2018). Understanding Conflict Resolution. SAGE Publications Limited.

Warjiyati, S. (2014). Calon Perseorangan Dalam Pemilihan Umum Kepala Daerah. AlDaulah: Jurnal Hukum Dan Perundangan Islam, 4(01), 112-135.

Winters, J. (2014). Understanding Conflict Resolution War, Peace And The Global System. California: Sage Publication.

\section{Tentang Penulis}

Mahpudin adalah mahasiswa Master Politik dan Pemerintahan, Universitas Gadjah Mada. Penulis memiliki minat riset seputar partai dan kepemiluan. 